\title{
Teaching Reform and Practice for Electrical Machinery *
}

\author{
Hailan Wang \\ Beijing Forestry University, Beijing 100083, China \\ wanghailan@bjfu.edu.cn
}

\begin{abstract}
Electrical machines is the main course for electrical engineering specialty. The quality of teaching has an important impact on the following professional courses. This paper provides reform and practice in the teaching approach for electrical machinery. By using multimedia development, internet google, and bilingual teaching, reform is put forward about teaching organization and design of teaching content, includes teaching methods and means, practise form. The object is to foster the applied ability of students as the core. It is helpful to confront underguaduate students in a more attractive and efficient way with electrical machines.
\end{abstract}

Index Terms - Electrical machinery, Teaching reform, multimedia development, Bilingual teaching.

\section{Introduction}

With the rapid development of technology and knowledge, Internet surfing is very popular in Phones, Computes, and society changed to a world of images. During these years, electrical energy is the more economic development lifeline in the world, and electrical machinery is the more important course in ability teaching for most colleges and universities. Electrical machinery has abstract theories and rich content, with much conception and contact tightly with engineering practice. So it is eager to stimulate the interest of the students in learing. By the process of tens years teaching, the reform ideas and practical experiences is produced in electrical machinery.

\section{Teaching Approach}

Since electrical machinery is the important element in power system, from 2000 Electrial Machinery was revised to a professional course of electrical engineering and automation specialty in our university. It is hard to teach and learn. So it brings new challenges and demands to the traditional teaching mode.

\section{A. Introduce multimedia technology}

Electrical machinery has abstract theories, such as the rotating magnetic field generated by alternate current in stator windings. Multimedia courserware concerns a collection of media like photos, animations, sound, diagram, television, video, images, etc. It is better way to demonstrate the machines' structure, composition, the theories and characteristics by multimedia vividly. It shows be effective on teaching and learning.

\section{B. Make use of internet}

At the same time, we assign homeworks for the students to google, for example the present and future of different electrical machines, the rotoe coils, the commucation function, etc. It enchance the ability for students to learn from Internet google.

\section{Combine with bilingual teaching}

With the rapid international development of 21st century, bilingual teaching is the inevitable trend for Chinese students. Learning professional theory in professional foreign languages will make students to have more chance to commutate with the professional foreign expert and expand their knowledge, such as the present and future of different electrical machines, the useful micro-motor.

\section{Combine with simulation software}

Using the powerful computer software Matlab, it is easy to simulate the steady and transient process of electrical machinery, show the waves timely about the current, the voltage, the torque, the rotate speed, etc. It can stimulate the interest of the student to understand the work condition.

\section{Experiment and Practice}

In the basis of the traditional textbook experiment, two other practice aspects are introduced for students in our course.

\section{A. Making simply machine by themselves}

Simply machine was assigned for homework to exercise understanding and operation. Some students make dc motor, some make dc generate, some make transformer, etc. By finishing this homework, students find and assemble the main poles, the coils, the brushes, the commutation, etc. At last they can understand the principle and construction of machines very deeply.

\section{B. Adding the course design}

In the course design, different knowledge students learned is required and should be combined with to complete a whole design task. For example, the system must use microchip or PLC to control a motor rotating, showing the speed in the LCD and alarming. At the same time a simulation software helps to give the image of some parameters. It make students to review all the knowledge they learnd, and mix up to finish the system.

\footnotetext{
* This work is partially supported by by the 2012 excellent course of Electrical Machines and Drives in Beijing Forestry University, Course construction and teaching methods of research on embedded microcomputer (BJFU2013JG035).
} 


\section{Conclusion}

During these years, it is verified that the use of flexible teaching methods and focusing on linking theory with practice can gain satisfactory results.

By training in experiments and practice, students can validation theories and operation skills, deepen understanding, enhance memory and stimulate interest in leaning. The practice and experiment are the indispensable parts in electrical machinery teaching.

\section{Acknowledgment}

The project supported jointly by the 2012 excellent course of Electrical Machines and Drives in Beijing Forestry University, Course construction and teaching methods of research on embedded microcomputer (BJFU2013JG035).

\section{References}

[1] Hongjie Xiao, Jinyu Song, Gang Wei. Exploration and practice of teaching reform approach for "Electrical Machines" course. Proceedings of the EPSA, Vol.13 No.5,75-77

[2] Wenxin Huang, Xuezhong Zhu, Chuang Liu. A creative discussion about open teaching of electrical machinery. Journal of EEE, Vol.28 No.6,109111

[3] http://wenku.baidu.com 